\title{
OPEN Author Correction: Sex-based Differences in the Association between Body Composition and Incident Fracture Risk in Koreans
}

\author{
Jung Hee Kim $D^{0}$, A. Ram Hong, Hyung Jin Choi, Eu Jeong Ku, Nam H. Cho \& Chan Soo Shin \\ Correction to: Scientific Reports https://doi.org/10.1038/s41598-017-06386-7, published online 20 July 2017
}

The original version of this Article omitted an affiliation for Jung Hee Kim. The correct affiliations for Jung Hee Kim are listed below:

Department of Internal Medicine, Seoul National University College of Medicine, Seoul, Republic of Korea

Department of Molecular Medicine and Biopharmaceutical Sciences, Graduate School of Convergence Science and Technology, Seoul National University, Seoul, Republic of Korea.

This has now been corrected in the HTML and PDF versions of this Article.

(c) (i) Open Access This article is licensed under a Creative Commons Attribution 4.0 International License, which permits use, sharing, adaptation, distribution and reproduction in any medium or format, as long as you give appropriate credit to the original author(s) and the source, provide a link to the Creative Commons license, and indicate if changes were made. The images or other third party material in this article are included in the article's Creative Commons license, unless indicated otherwise in a credit line to the material. If material is not included in the article's Creative Commons license and your intended use is not permitted by statutory regulation or exceeds the permitted use, you will need to obtain permission directly from the copyright holder. To view a copy of this license, visit http://creativecommons.org/licenses/by/4.0/.

(C) The Author(s) 2019 